\title{
DE HEMELSE DIENARES
}

Het beeld (afb. 1) stelt een vrouwenfiguur voor, waarvan de voeten en het onderste gedeelte van de linkerarm missen. Ze staat in de bekende tribangha houding; in haar rechterhand houdt ze een shriphala (de vrucht van de Bilvaboom, Aegle marmelos), aan het bovengedeelte van haar linkerarm is een gedeelte van de vliegenwaaier (chauri) te zien, die ze in haar linkerhand vasthield. Achter haar hoofd is een waaiervormig ornament (Siraschakra) aanwezig als een soort nimbus. Het enige kledingstuk dat ze draagt bedekt haar onderlichaam en haar benen tot onder de knieën. Het meest in het oog springende kenmerk van het beeld is echter wel het overdadige gebruik van sieraden, die bijna het gehele kapsel, maar ook grote gedeelten van het boven- en onderlichaam bedekken. In lussen vallende parelsnoeren en rozetten bezet met juwelen zijn de belangrijkste onderdelen. Het haar dat onder de hoofdbedekking uitkomt is in stijve krulletjes opgerold.

De dame is door de vliegenwaaier gemakkelijk te herkennen als een begeleidende figuur, die ooit een belangrijker godheid op een tempelmuur geflankeerd heeft. De vrucht kan beschouwd worden als een symbool van vruchtbaarheid en overvloed en zij moet daarom als een vruchtbaarheidsnimf gezien worden. Dit wordt nog verder benadrukt door haar prominente borsten en wijde heupen.

Afbeelding $\mathbf{1}$ (links) Hemelse dienares, leisteen h. $83,0 \mathrm{~cm}$. India, Karnataka, midden $12^{\mathrm{e}}$ eeuw Rijksmuseum, inv.nr. AK-RAK-1975-2

\section{Afbeelding 2} Detail van de Hoysalesvara temple India, Halebid, $3^{\mathrm{e}}$ kwart $12^{e}$ eeuw Uit: B. Rowland, The Art and Architecture of India, Harmondsworth en New York, 1984, p. 324

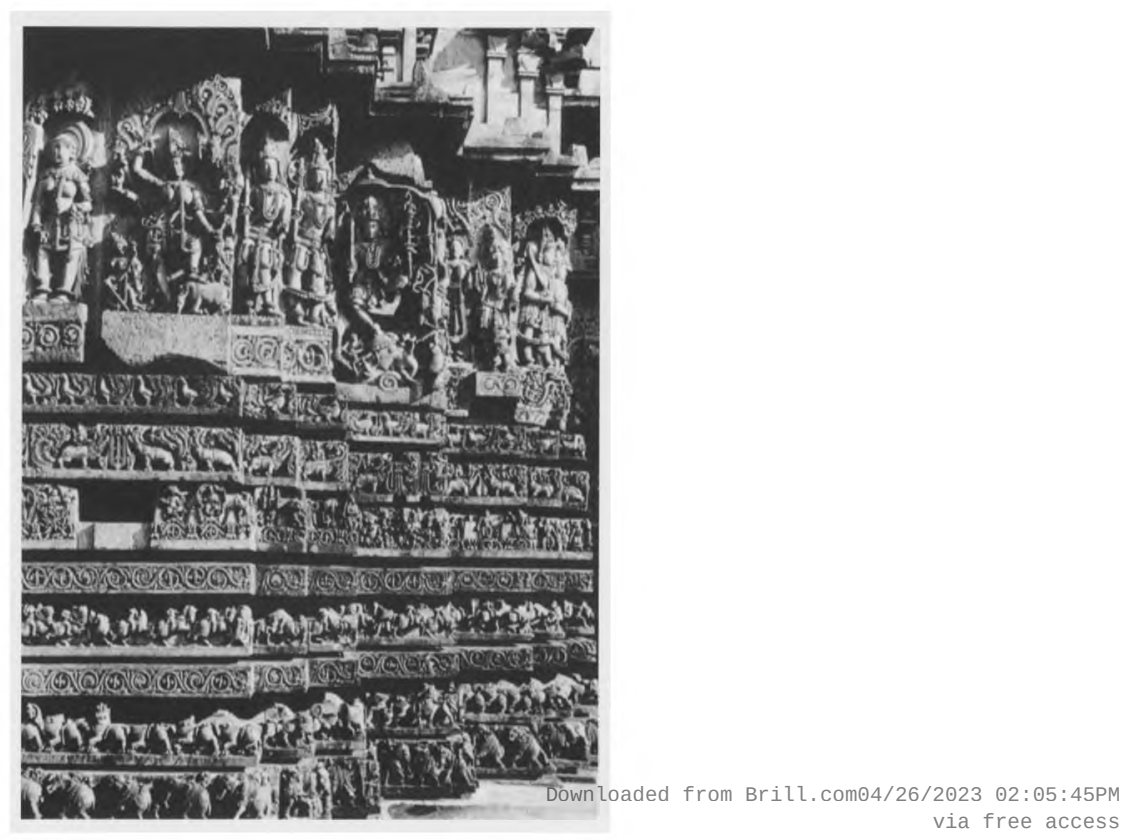


Het beeld is een typisch voorbeeld van de rijpe Hoysala-stijl uit ongeveer de $12^{\mathrm{e}}$ eeuw. Het lijkt in de stijl van de figuren op de muren van de Hoysalesvara-tempel in Halebid te passen. Deze tempel is gebouwd tijdens de regering van koning Narasimha I (1152-1173). De Hoysala's waren van oorsprong een bergstam, die ten zuiden van het huidige Mumbay aan de westkant van het Indiasche subcontinent woonden in het gebied van het huidige Mysore.

Pratapaditya Pal schreef bij de aankoop van het beeld in een artikel in dit tijdschrift ${ }^{1}$ al over de rijke Hoysala-stijl:

"Hoysala sculpture is characterized by a remarkable harmonious blend of extravagant form and ornateness. Despite the profusion of ornaments, which are rendered with a jewellers finesse and precision, the underlying form retains its opulent prominence. Nevertheless the term 'rococo' immediately springs to mind when one views Hoysala sculpture, especially as it is employed to embellish the temple walls." (afb. 2)

Dat wil zeggen dat dit beeld, dat zo uitvoerig en zorgvuldig uitgewerkt is, een onderdeel gevormd heeft van een tempelmuur die zo overdadig versierd was met beeldhouwwerk, dat de individuele beelden nauwelijks opvielen. Een andere kunsthistoricus spreekt van "incrustation of sculpture", "over-ripeness and decadence" en "wedding-cake embellishment". Misschien is onze Hemelse Dienares niet zo slecht af met een plaatsje in het museum.

\section{Noot}

1. Pratapaditya Pal schreef in het Bulletin van de Vereniging van Vrienden van de Aziatische Kunst in 1975, derde serie nr. 23 een artikel genaamd 'A celestial lady from Mysore', ter gelegenheid van de verwerving van het beeld. 